\title{
Economic aspects of biosimilar competition in Hungary The treatment of rheumatic disorders
}

\author{
ZSOMBOR ZRUBKA \\ PhD candidate, Corvinus University of Budapest, Department of Health Economics \\ Specialty business unit manager, Sandoz Hungária Kft. \\ E-mail: zsombor.zrubka@googlemail.com
}

\begin{abstract}
Biologicals are the fastest growing segment of the global pharmaceutical market, reaching 199 billion USD sales per year with 9.8\% 10-year compound annual growth rate (CAGR). Being less costly, yet equally efficacious and safe alternatives to originator reference products, biosimilars drive competition, promise budget savings and the opportunity for better patient-access. This paper examines the key factors and players of biosimilar competition in rheumatology in Hungary. Due to the scarcity of data, the total yearly expenditure on biologicals could only be estimated from different data sources. In 2015 the estimated expenditure on biologicals was around 100 billion HUF. In rheumatology indications the expenditure on biologicals was 10 (8.9-11.2) billion HUF, and the average annual net treatment cost was 1.2 (1.06-1.34) million HUF / per patient / year. The magnitude of societal benefits in terms of budget savings and health gains may result from the joint effort of policy makers, funders, physicians and patients. In rheumatology indications, biosimilar utilization could be increased by a policy supporting physician-driven interchange of the reference product to biosimilars. Also, creating a physician inventive system for broader use should be considered in order to realize the full economic advantages of biosimilars and contribute to sustainable healthcare financing in Hungary.
\end{abstract}

JEL: I1 1

Keywords: biosimilar, rheumatology, Hungary

\section{Introduction}

Biological medicines are large complex molecules, which are made or derived from a biological source (EMA 2016b). With 9.8\% 10-year compound annual growth, biologicals are the fastest growing segment of the global pharmaceutical market, reaching 199 billion USD sales 25\% market-share by 2016 (Evaluate Pharma 2015). Biologicals are expensive and their expanding use represents significant economic burden worldwide. In 2015 in Hungary the estimated expenditure on biological medicines was 100 billion HUF (WHO 2011, OEP 2016, OEP 2016).

After the expiry of the patent protection of originator biological molecules, their less costly alternatives, biosimilars can enter the market with the promise of savings in the healthcare budget or enabling better patient access to biological treatment (Gulácsi et al. 2015). Biosimilars are developed to be similar to already authorized reference biological medicines. 
Biosimilars have essentially the same structure as their reference originator molecules and have no meaningful differences in efficacy, safety and quality (EMA 2016b). Due to size and complexity of biosimilar molecules, their marketing authorization pathway ${ }^{1}$ is different from originator or generic medicines. The specific biosimilar regulatory status required public health insurers to establish new biosimilar reimbursement techniques. The uptake of biosimilars in Europe in 2014 has shown considerable variance between countries ranging between $2-100 \%$ for filgrastim ${ }^{2}$ (EU average: $81 \%$ ), 0-100\% for erythropoietin ${ }^{3}$ (EU average: $43 \%$ ), $0-99 \%$ for somatropin ${ }^{4}$ (EU average: 33\%), 0-19\% for infliximab (EU average: $1 \%$ ) which indicates the initial challenges of their efficient utilization (IMS Health 2015).

Biological drugs brought breakthrough in the treatment of three chronic, progressive inflammatory rheumatic conditions (rheumatoid arthritis- $\mathrm{RA}^{5}$, ankylosing spondylitis - $\mathrm{AS}^{6}$ and psoriatic arthritis - $\mathrm{PsA}^{7}$ ). Without effective treatment, these conditions lead to work disability and reduced quality of life and thus impose substantial burden on the society. (Péntek et al. 2014) The biological drugs used in rheumatology indications belong to the family of monoclonal antibodies (mAbs), and will be referred to as biologicals in the article. These molecules are also used in other disease areas such as gastroenterology or dermatology, which are covered when necessary for the analysis.

Rheumatology is the biggest therapeutic area where biosimilars of several different biologicals will compete in the next few years. Two biosimilars received marketing authorization in September 2013, an additional two in 2016, and more biosimilars are under evaluation by the EMA (EMA 2016c). With 10 registered original, 4 biosimilar as well as several emerging new molecules, the European rheumatology biological market is a competitive arena with increasingly important economic consequences of choosing between alternative molecules (Dorner et al. 2016).

The scientific innovation of biological drugs and biosimilars brought new economic challenges, which is being followed by innovation in resource allocation and reimbursement decision making. The importance of pharmacoeconomic analysis will increase, while valid data about biological treatments and the respective indications are scarce in the public domain. By using existing literature and public data sources, the aim of the article is to

\footnotetext{
${ }^{1}$ Marketing authorization is the process of regulatory review and approval of medicines by a competent regulatory authority, performed within a specific legislative framework.

${ }^{2}$ Filgrastim is used for the treatment or prevention of neutropenia (low white blood cell count) associated with cancer treatment and various other conditions. The first biosimilar filgrastim received European marketing authorization in 2008.

${ }^{3}$ Erythropoietin is used for the treatment of anaemia (low red blood cell count) associated with cancer or chronic renal failure. The first biosimilar erythropoietin received European marketing authorization in 2007.

${ }^{4}$ Somatropin is human growth hormone, used for the treatment of various conditions associated with growth disturbances or growth hormone deficiency. The first somatropin biosimilar received European marketing authorization in 2006.

${ }^{5}$ Rheumatoid arthritis (RA) is a chronic inflammatory disease characterized by swelling, tenderness and destruction of joints, leading to severe functional disability, lowered quality of life and premature mortality (Péntek et al. 2014)

${ }^{6}$ Ankylosing spondylitis (AS) is a chronic inflammation of the spine, joints and internal organs, leading to loss of spinal mobility and eventual disability (Péntek et al. 2014)

${ }^{7}$ Psoriatic Arthritis (PsA) is a heterogeneous inflammatory disorder affecting the joints, skin and nails, leading to significant impairment of quality of life, psychosocial disability and productivity loss (Péntek et al. 2014)
} 
analyze the total expenditure, cost per patient and level of patient access to biologicals in rheumatology indications in Hungary, as well as the uptake of biosimilars and the factors affecting biosimilar competition.

\section{Costs of biological treatment}

\subsection{Global expenditure on rheumatology biologicals}

In 2014 seven out of the 10 global best selling drugs were biologicals. Four of them had rheumatology indications (Nisen 2016). The nine rheumatology biologicals in 2014 had an estimated 47.8 bn USD global sales, accounting for $26.5 \%$ of global biological sales and an estimated $6 \%$ of global pharmaceutical sales (see Table 1). A novel rheumatology biological (secukinumab) was authorized in 2015 in the EU. Biosimilar infliximab (Inflectra and Remsima, originator reference product: Remicade) sales data from 2014 were not available in company reports. The sales split by therapeutic areas is not provided in global data sources, therefore global expenditure on rheumatology indications is not known.

Table 1. Global sales of rheumatology biologicals* in 2014

\begin{tabular}{lcc}
\hline Brands & 2014 sales* $^{*}$ & Growth vs 2013 \\
\hline Humira (adalimumab) $^{\mathrm{a}}$ & 13.02 bn USD & $17 \%$ \\
Remicade (infliximab) $^{\mathrm{a}}$ & 10.15 bn USD & $3 \%$ \\
Enbrel (etanercept) $^{\mathrm{a}}$ & 9.12 bn USD & $3 \%$ \\
Mabthera (rutixumab) $^{\mathrm{a}}$ & 7.36 bn USD & $-1 \%$ \\
Stelara (ustekinumab) $^{\mathrm{b}}$ & 2.07 bn USD & $38 \%$ \\
Simponi (golimumab) $^{\mathrm{b} . \mathrm{e}}$ & 1.88 bn USD & $31 \%$ \\
Orencia (abatacept) $^{\mathrm{c}}$ & 1.65 bn USD & $14 \%$ \\
Actemra / Roactemra (tocilizumab) $^{\mathrm{d}}$ & 1.12 bn USD & $23 \%$ \\
Cimzia (certolizumab) $^{\mathrm{f}}$ & 1.06 bn USD & $34 \%$ \\
\hline Total & 47.4 bn USD & $+9 \%$ \\
\hline
\end{tabular}

*All indications, sales split by therapeutic areas are not provided in global data sources Sources: ${ }^{a}$ PMLiVE (2014), b J \& Annual Report (2014), ${ }^{\mathrm{c}}$ Statista (2016a), ${ }^{\mathrm{d}}$ Roche Annual Report (2014), ${ }^{\mathrm{e}}$ Merck Annual Report (2014), ${ }^{\mathrm{f}}$ UCB Annual Report (2014), ${ }^{\mathrm{g}}$ Credit Suisse (2014), ${ }^{\mathrm{h}}$ Statista (2016b)

\subsection{Expenditure on biologicals in rheumatology indications in Hungary}

The total yearly expenditure on biologicals and share of rheumatology indications can only be estimated from a variety of publicly available data sources. The following section describes the Hungarian market and estimates the expenditure on biologicals in rheumatology indications.

Despite national health budget deficits (Boncz - Sebestyen 2006), rheumatology biologicals gained reimbursement in 2006, and currently can be prescribed in 21 authorized centers (Poór 2015). The Hungarian National Health Insurance Fund Administration (OEP) covers $100 \%$ of the drug costs. In March 2016, nine originator biologicals and one biosimilar (infliximab) were reimbursed.

Since February 2012, rheumatology biologicals have been financed via the itemized payment 
system. This system enables OEP the control of usage per financial protocol for each individual patient. Rheumatology biologicals are purchased via public procurement tenders by the OEP. Corresponding wholesaler delivery contracts are published, while prices, discounts and patient-numbers are kept confidential (OEP 2016b), making the precise economic analysis of this high value public spending difficult.

The expenditure on biologicals was estimated from the 38 wholesaler delivery contracts ${ }^{8}$ (see Table 2) The first contracts started on $1^{\text {st }}$ February 2012, and the last reconciliation period ended on $29^{\text {th }}$ February 2016 (OEP 2016c). With the exception of Mabthera, contract values for brands are not separated by therapeutic area, therefore expenditure on rheumatology indications cannot be calculated directly. From the 62.5 billion HUF total, 50.9 billion HUF was the 4-year contracted base value of rheumatology, gastroenterology and dermatology indications combined. Expenditure on rheumatology indications is not separated in the contracts, it needs to be estimated from patient-numbers.

Table 2. Expenditure on rheumatology biologicals from February 2012 to February 2016 in Hungary (bn HUF)

\begin{tabular}{lccc}
\hline Brands & Minimum* & Base* & Maximum* \\
\hline Humira (adalimumab) & 11.9 & 13.5 & 15.1 \\
Mabthera (rituximab) total** & 11.9 & 13.4 & 14.9 \\
$\quad$ Mabthera hematology & 10.4 & 11.6 & 12.9 \\
Mabthera rheumatology & 1.6 & 1.8 & 2.1 \\
Enbrel (etanercept) & 10.0 & 11.3 & 12.6 \\
Remicade (infliximab) & 9.1 & 10.1 & 11.1 \\
Simponi (golimumab) & 4.2 & 4.7 & 5.2 \\
Cimzia (certolizumab) & 3.1 & 3.1 & 3.2 \\
Roactemra (tocilizumab) & 2.6 & 3.1 & 3.6 \\
Stelara (ustekinumab) & 1.7 & 2.0 & 2.3 \\
Inflectra (biosimilar infliximab) & 0.6 & 0.8 & 1.0 \\
Orencia (abatacept) & 0.1 & 0.3 & 0.4 \\
\hline Total & 55.3 & 62.5 & 69.7 \\
\hline Rheumatology, gastroenterology and dermatology indications*** & 45.0 & 50.9 & 56.8 \\
\hline
\end{tabular}

* Most contracts specify a base value as well as optional deviations upwards or downwards. Apart from the sum of base values, a potential minimum and a maximum expenditure was calculated by adding up all positive and negative optional deviations.

**Separate contracts indicate that $13.6 \%$ of Mabthera expenditure was spent on rheumatology and $86.4 \%$ on hematology indications. For other brands, the split between therapeutic areas was not provided in the contracts. *** Total contract value remaining after the deduction of expenditure on Mabthera hematology indications. Source: (OEP 2016c)

The number of rheumatology, gastroenterology and dermatology patients receiving biologicals have recently been published for the period 2006-2014 (Poór 2015). In 2014 in rheumatology indications 8374 patients received biologicals. The growth rate and proportion

\footnotetext{
${ }^{8}$ Public procurement frame contracts specify the total demand and maximal value calculated on public prices. Corresponding wholesaler delivery contracts specify the actual purchase value for specific periods, but do not provide details of the purchased amount or the actual prices.
} 
of rheumatology relative to other therapeutic areas slightly decreased between 2013 and 2014 from $9.1 \%$ to $7.6 \%$ and $71.2 \%$ to $69.3 \%$, respectively (see Table 3 ).

Table 3. Patients treated with rheumatology biologicals in Hungary between 2012-2015

\begin{tabular}{llccccc}
\hline Year & & 2012 & 2013 & 2014 & $2015 *$ & Total \\
\hline \multirow{5}{*}{ Rheumatology } & Treated patients & 6591 & 7188 & 7781 & 8374 & 29934 \\
& \% of all patients & $71.9 \%$ & $71.2 \%$ & $70.1 \%$ & $69.3 \%$ & $70.5 \%$ \\
& Difference vs previous year & 637 & 597 & 593 & 593 & - \\
& Growth vs previous year & - & $9,1 \%$ & $8,2 \%$ & $7,6 \%$ & - \\
\hline \multirow{5}{*}{ Gastroenterology } & Treated patients & 1433 & 1632 & 1845 & 2058 & 6968 \\
& \% of all patients & $15.6 \%$ & $16.2 \%$ & $16.6 \%$ & $17.0 \%$ & $16.4 \%$ \\
& Difference vs previous year & 87 & 199 & 213 & 213 & - \\
& Growth vs previous year & - & $13,9 \%$ & $13,1 \%$ & $11,5 \%$ & - \\
\hline \multirow{5}{*}{ Dermatology } & Treated patients & 1137 & 1281 & 1468 & 1655 & 5541 \\
& \%of all patients & $12.4 \%$ & $12.7 \%$ & $13.2 \%$ & $13.7 \%$ & $13.1 \%$ \\
& Difference vs previous year & 77 & 144 & 187 & 187 & - \\
\hline \multirow{5}{*}{ Total } & Growth vs previous year & - & $12,7 \%$ & $14,6 \%$ & $12,7 \%$ & - \\
& Treated patients & 9161 & 10101 & 11094 & 12087 & 42443 \\
& Difference vs previous year & 801 & 940 & 993 & 993 & - \\
& Growth vs previous year & - & $10,3 \%$ & $9,8 \%$ & $9,0 \%$ & - \\
\hline
\end{tabular}

* Patient-numbers for 2015 were estimated by assuming the same absolute change versus the previous year as in 2014.

Source: (Poór 2015)

The yearly expenditure on biological treatment by therapeutic area can be estimated from from the overlapping contract values and patient-numbers (see Table 4). It is estimated that 8.6, 9.3 and 10.0 billion HUF was spent on the biological treatment of rheumatology indications in 20132014 and 2015 respectively.

Table 4. Estimated yearly treatment expenditure on biologicals by therapeutic area (bn HUF)

\begin{tabular}{lcccccccccc}
\hline & \multicolumn{2}{c}{ Rheumatology indications } & \multicolumn{2}{c}{ Gastroenterology indications } & \multicolumn{3}{c}{ Dermatology indications } \\
\cline { 2 - 10 } Year & Min & Base & Max & Min & Base & Max & Min & Base & Max \\
\hline 2012 & 7.0 & 7.9 & 8.8 & 1.5 & 1.7 & 1.9 & 1.2 & 1.4 & 1.5 \\
2013 & 7.6 & 8.6 & 9.6 & 1.7 & 2.0 & 2.2 & 1.4 & 1.5 & 1.7 \\
2014 & 8.2 & 9.3 & 10.4 & 2.0 & 2.2 & 2.5 & 1.6 & 1.8 & 2.0 \\
2015 & 8.9 & 10.0 & 11.2 & 2.2 & 2.5 & 2.8 & 1.8 & 2.0 & 2.2 \\
\hline $2012-15$ & 31.7 & 35.9 & 40.1 & 7.4 & 8.4 & 9.3 & 5.9 & 6.6 & 7.4 \\
\hline
\end{tabular}

Coverage period for expenditure data: February 2012-February 2016; for patient data: January 2012 - December 2015. The expenditure on rheumatology, gastroenterology and dermatology indications was assumed to be proportional with the published patient-numbers. Potential differences between dosing or usage of drugs across indications were not taken into consideration. The precision of the estimate was acceptable despite the 1-month mismatch between the covered periods. Yearly expenditure on the hematology indications of Mabthera was assumed to be constant between 2012 and 2015. The estimates based on the minimum and maximum optional procurement contract values are also provided.

Source: author 
In 2014 the state expenditure on pharmaceuticals was 302.3 billion HUF (Magyar Államkincstár 2014). The estimated expenditure on rheumatology biologicals was 17.1 billion HUF (15.2-19.1), which is $5.7 \%(5.0-6.3 \%)$ of the national pharmaceutical budget, similar to the global $6 \%$ expenditure on these molecules. On rheumatology indications approximately 9.3 billion HUF (8.9-11.2) was spent, which is $3.3 \%(2.9-3.7 \%)$ of the national pharmaceutical budget. It has to be noted that hospital drug costs and the itemized payment system are not included in the national pharmaceutical budget. Also, in 2014 the pharmaceutical manufacturers paid 57.4 billion HUF back to the national health fund as special taxes and charges (Healthware 2015). Therefore, the share of biologics within the total net pharmaceutical expenditure cannot be estimated precisely from public data.

\subsection{Costs of biological drugs per patient}

The annual treatment with a biological drug costs on average 20 times more than with traditional pharmaceuticals (Emerton 2013). In Western Europe the yearly cost with biologicals in rheumatology indications were reported between 9000 and 18000 EUR (Kobelt and Kasteng 2009; Zeidler et al. 2012; Lekander et al. 2013).

In Hungary, according to the OEP prescription database analysis, the average cost per patient / year of the 8 rheumatology biologicals increased from 7964 EUR in 2006 to 9229 EUR (2.77 million HUF) by 2010 (Laki et al. 2013). The calculation of real world costs from procurement contracts and patient data (see Table 3 and Table 4) suggests that between 2012 and 2015 the average biological treatment cost was 1.2 million HUF per patient / year (range: $1.06-1.34$ ), which is $56 \%$ lower than the 2010 costs reported by Laki et al. The explanation for the difference may be related partly to the bias of the estimate and also that the confidential price discounts, free goods and risk sharing ${ }^{9}$ agreements reflected in the procurement contracts were not reported in the OEP database. Price changes over time cannot be calculated from the available data (Laki et al. 2013; OEP 2016c).

These findings are concordant with the report of Gulácsi et al. who indicated that due to various risk-sharing agreements, actual purchase prices of rheumatology biologicals in Hungary may be approximately 50\% lower than list prices (Gulácsi et al. 2014).

\section{Access to biological treatment in rheumatology}

\subsection{Methodological considerations}

Authors unequivocally conclude that there are significant inequities of access to biologicals between European countries (Putrik et al. 2014; Gulácsi et al. 2016). Less inequity and improved patient-access to biological treatments are among the most important expected societal benefits of biosimilars. However, due to the dynamic growth of biological sales and the lack of objective measures of optimal patient-access, quantifying the effect of biosimilars

\footnotetext{
${ }^{9}$ The wholesaler delivery contracts specify several ways of sharing the financial risks related to uncertain treatment costs or treatment effect with manufacturers. Examples include caps on paid doses, free goods for the induction phase of therapy or transferring the cost of waste due to mismatch between opened vials and the administered dose to patients. Expert reports also refer to price-volume agreements, and cost-volume and outcome guarantees. (OEP 2016c; Gulácsi et al. 2014)
} 
can be challenging.

Rheumatology biologicals are used in several indications in different therapeutic areas, and their usage relative to alternative treatments varies largely. Population biological utilization rates measure consistently the overall access to these drugs, but do not provide insight into access levels and potential inequities between therapeutic areas or indications. Several authors report treatment rates of diagnosed patients (Kobelt - Kasteng 2009; Orlewska et al. 2011; Péntek et al. 2014; Poór 2015). It is important to note that methodological differences and different time-points of epidemiological studies resulted in wide variance of disease prevalence estimates (Kiss et al. 2005; Hanova et al. 2006; Kobelt and Kasteng 2009; EUMUSC 2011). Also, reports on the number of patients taking biologicals may rely on estimates from a mixture of sources. (Kobelt - Kasteng 2009; Orlewska et al. 2011; Péntek et al. 2014; Poór 2015) Although published studies provide valuable cross-sectional comparison of biological treatment rates in different time-points, there is insufficient research on the evolution of the diagnosis and biological treatment rates over time. In order to measure the effect of biosimilars on patient-access accurately, a consistent methodology is needed across time. Valid methods for cross-sectional as well as time-series analysis may result in significantly different point estimates of patient-access.

\subsection{Access to biological therapy in rheumatology indications}

The biological treatment rates of RA, AS and PsA were calculated using patient-numbers from the National Healthcare Service Center (ÁEEK) database (ÁEEK 2016), and published numbers of patients treated with biologicals for 2009, 2013 and 2014 (see Table 5). The results suggest that the number of patients increased in all indications over the past 5 years. The treatment rates with biologicals in RA increased considerably between 2009 and 2013 and stagnated in 2014. Contrary to RA, treatment rates increased slightly in AS and PsA between 2013 and 2014.

The number of diagnosed RA and PsA patients were within the range of available disease prevalence data for Hungary and Europe. The number of diagnosed AS patients is lower than expected from epidemiological data.

Table 5. Biological treatment rates of rheumatology indications in Hungary

\begin{tabular}{lcccc}
\hline & Year & RA & AS & PsA \\
\hline $\begin{array}{l}\text { Disease prevalence \% in } \\
\text { Hungary (EU range) }\end{array}$ & & $\begin{array}{c}0.37-0.48 \% \%^{\mathrm{a}, \mathrm{b}} \\
(0.32-0.82 \%)^{\mathrm{b}}\end{array}$ & $\begin{array}{c}0.23 \%^{\mathrm{d}} \\
(0.19-0.24 \%)^{\mathrm{d}}\end{array}$ & $\begin{array}{c}\text { na } \\
(0.05-0.42 \%)^{\mathrm{e}}\end{array}$ \\
\hline Number (\%)* of diagnosed & 2009 & $35080(0.41 \%)$ & $6945(0.08 \%)$ & $5940(0.07 \%)$ \\
patients $^{\mathrm{f}, \mathrm{g}}$ & 2013 & $37777(0.45 \%)$ & $8162(0.10 \%)$ & $6978(0.08 \%)$ \\
\hline Number of patients taking & 2014 & $38203(0.45 \%)$ & $8612(0.10 \%)$ & $6944(0.08 \%)$ \\
biologicals & 2009 & $2048^{\mathrm{h}}$ & na & na \\
& 2013 & $4565^{\mathrm{i}}$ & $1955^{\mathrm{i}}$ & $894^{\mathrm{i}}$ \\
\hline \% of Hungarian patients & 2009 & $4510^{\mathrm{j}}$ & $2125^{\mathrm{j}}$ & $905^{\mathrm{j}}$ \\
treated with biologicals & 2013 & $12.1 \%$ & na & na \\
\end{tabular}


* Number of $>15$-year-old patients in AEEK database as percentage of $>15$-year-old population Sources: ${ }^{\mathrm{a}}$ Kiss et al. (2005), ${ }^{\mathrm{b}}$ Kobelt and Kasteng (2009), ${ }^{\mathrm{c}}$ EUMUSC (2011), ${ }^{\mathrm{d}}$ Dean et al. (2014), ${ }^{\mathrm{e}}$ Catanoso et al. (2012), ${ }^{\mathrm{f}}$ AEEK (2016), ${ }^{\mathrm{g}} \mathrm{KSH}$ (2016), ${ }^{\mathrm{h}}$ Orlewska et al. (2011), ${ }^{\mathrm{i}}$ Péntek et al. (2014), ${ }^{\mathrm{j}}$ Poór (2015).

Cross-sectional data from six CEE countries in 2013 (see Table 6) indicate that despite the similar economic performance, there are significant variances of patient access to biological therapy across the three rheumatology indications. The combined biological treatment rate in Hungary $(11.8 \%)$ was the highest in the region.

Table 6. Treatment rates with biologicals of rheumatology indications in 2013 in 6 CEE countries

\begin{tabular}{lccccccccc}
\hline & \multicolumn{3}{c}{ Rheumatoid Arthritis } & \multicolumn{2}{c}{ Ankylosing spondylitis } & \multicolumn{3}{c}{ Psoriatic Arthritis } \\
\cline { 2 - 10 } & $\begin{array}{c}\text { Diagnosed } \\
\text { patients }\end{array}$ & $\begin{array}{c}\text { Patients } \\
\text { on } \\
\text { biologics }\end{array}$ & $\begin{array}{c}\text { Treatment } \\
\text { rate }\end{array}$ & $\begin{array}{c}\text { Diagnosed } \\
\text { patients }\end{array}$ & $\begin{array}{c}\text { Patients } \\
\text { on } \\
\text { biologics }\end{array}$ & $\begin{array}{c}\text { Treatment } \\
\text { rate }\end{array}$ & $\begin{array}{c}\text { Diagnosed } \\
\text { patients }\end{array}$ & $\begin{array}{c}\text { Patients } \\
\text { on } \\
\text { biologics }\end{array}$ & $\begin{array}{c}\text { Treatment } \\
\text { rate }\end{array}$ \\
\hline Bulgaria & 38000 & 979 & $2,6 \%$ & 5900 & 766 & $13,0 \%$ & 3100 & 276 & $8,9 \%$ \\
Czech Republic & 54100 & 2295 & $4,2 \%$ & 8400 & 260 & $3,1 \%$ & 4300 & 150 & $3,5 \%$ \\
Hungary & 50800 & 4565 & $9,0 \%$ & 7800 & 1955 & $25,1 \%$ & 4100 & 894 & $21,8 \%$ \\
Poland & 197200 & 2569 & $1,3 \%$ & 30500 & 1261 & $4,1 \%$ & 15800 & 581 & $3,7 \%$ \\
Romania & 101600 & 4153 & $4,1 \%$ & 15700 & 2580 & $16,4 \%$ & 8200 & 969 & $11,8 \%$ \\
Slovakia & 27600 & 2765 & $10,0 \%$ & 4300 & 265 & $6,2 \%$ & 2200 & 325 & $14,8 \%$ \\
\hline
\end{tabular}

Patient-numbers were calculated for the $>16$ years old population using 2002-2003 prevalence data from the Czech Republic and Eurostat data. The patient-numbers taking biologicals were derived from national health insurance databases or national registries as well as best estimates from various sources.

Source: Péntek et al. (2014)

Treatment rates for 20 European countries in 2008 (Kobelt - Kasteng 2009) and 2013 (Poór 2015) suggest a considerable increase of patient access to biologicals in RA over time. (Table 7) The biological treatment rates in Hungary were below the Western European average in $2008(3.9 \%$ vs $11.1 \%)$ as well as in $2013(9.0 \%$ vs $14.5 \%)$.

Table 7. Biological treatment rates of RA in European countries

\begin{tabular}{ll}
\hline & $2008^{\mathrm{a}}$ \\
\hline Norway & \\
Belgium & $28.7 \%$ \\
Ireland & $20.2 \%$ \\
Denmark & $19.9 \%$ \\
Spain & $17.4 \%$ \\
Sweden & $16.7 \%$ \\
Greece & $15.9 \%$ \\
Finland & $15.2 \%$ \\
France & $13.9 \%$ \\
Netherlands & $12.7 \%$ \\
E13* & $12.3 \%$ \\
& $11.1 \%$
\end{tabular}

\begin{tabular}{ll}
\hline & $2013^{\mathrm{b}}$ \\
\hline Norway & $37.4 \%$ \\
Ireland & $34.0 \%$ \\
Sweden & $29.9 \%$ \\
Netherlands & $28.3 \%$ \\
Finland & $26.1 \%$ \\
Austria & $22.6 \%$ \\
Belgium & $22.3 \%$ \\
Denmark & $18.8 \%$ \\
Greece & $17.4 \%$ \\
Spain & $15.3 \%$ \\
United Kingdom & $15.3 \%$
\end{tabular}




\begin{tabular}{llll} 
United Kingdom & $10.1 \%$ & $W E U^{*}$ & $14.5 \%$ \\
Germany & $8.0 \%$ & Germany & $14.4 \%$ \\
Italy & $7.0 \%$ & France & $11.0 \%$ \\
Portugal & $5.6 \%$ & Italy & $9.7 \%$ \\
Czech Republic & $5.4 \%$ & Hungary & $9.0 \%$ \\
Austria & $4.2 \%$ & Portugal & $6.5 \%$ \\
Hungary & $3.9 \%$ & Slovakia & $6.5 \%$ \\
Slovakia & $3.8 \%$ & Czech Republic & $4.7 \%$ \\
Romania & $1.5 \%$ & Romania & $3.4 \%$ \\
Poland & $0.8 \%$ & Poland & $1.6 \%$ \\
\hline
\end{tabular}

*E13 countries: Austria, Belgium, Denmark, Finland, France, Germany, Italy, Netherlands, Norway, Spain, Sweden, Switzerland, United Kingdom

**Western and Northern Europe

Source: ${ }^{\mathrm{a}}$ Kobelt and Kasteng (2009), ${ }^{\mathrm{b}}$ Poór (2015)

International publications on the utilization rates of biologicals in AS and PsA are scarce. In 2004-2005 the biological treatment rate in AS was 17\% in Spain (Kobelt et al. 2008). In the Czech Republic in two cross-sectional studies $2.9 \%$ and $6.3 \%$ of AS patients were treated with biologicals in 2005 and 2008, respectively (Hanova et al. 2010). In Belgium 44\% AS biological treatment rate was reported in 2009. In $201158 \%, 48 \%$ and $50-55 \%$ of AS patients received biologicals in Portugal, Canada and the US, respectively. The biological treatment rate of PsA was 12\% in Spain in 2005 and 52\% in Portugal in 2011 (Reveille et al. 2012).

The striking differences of patient access to biologicals between countries cannot be explained by different medical need alone. Economic and health policy differences are significant contributors to inequity of access within Europe. In all rheumatology indications the level of access to biologicals is higher in Hungary than in other CEE countries, while the lag compared to Western Europe is considerable. Although optimal treatment levels with biologicals have not been determined, the results suggest that in Hungary the medical need to treat more patients with biologicals will prevail for several more years.

\section{Biosimilar competition}

\subsection{Biosimilar uptake}

In March 2016 three biosimilars were available for rheumatology indications in Europe. In 2014 reports on biosimilar infliximab market shares were available from nine countries for comparison, including Hungary (see Table 8). Biosimilar infliximab was launched in the major EU markets after the patent expiry in 2015. Biosimilar etanercept was registered in January 2016 and no market uptake data has been published so far.

Table 8. Uptake of biosimilar infliximab in European markets in 2014

\begin{tabular}{lcc}
\hline Country & $\%$ vs Reference Product* & $\%$ vs TNF Inhibitor Market \\
\hline Norway & $19 \%$ & $8 \%$ \\
Poland & $11 \%$ & $3 \%$ \\
Hungary & $7 \%$ & $2 \%$ \\
Czech Republic & $3 \%$ & $2 \%$
\end{tabular}


$3 \% \quad 1 \%$

Ireland

$2 \%$

$1 \%$

Portugal

$2 \%$

$1 \%$

Romania

$2 \%$

$1 \%$

Slovakia

$1 \%$

$1 \%$

EU average

$1 \%$

$1 \%$

*Reference product: Remicade (infliximab). TNF Inhibitor mAbs: Cimzia (certolizumab), Enbrel (etanercept), Humira (adalimumab), Remicade (infliximab), Simponi (golimumab)

Source: IMS Health (2015)

For 2015 only sporadic market uptake data were published. The value market share of biosimilar infliximab between January and September 2015 was 8\% in Europe (Daubenfeld et al. 2016). In Poland a 67\% market-share was reported in May 2015 (epgonline.org 2015). In Norway the market-share of biosimilar infliximab reached 54\% by April 2015 (Mack 2015) and $79.9 \%$ in August 2015. The market share was 96.2\% in Denmark in October (Stanton 2016).

From the two registered biosimilar infliximab brands in Hungary, until March 2016 only one (Inflectra) gained reimbursement in the procurement tenders starting from May 2014 (OEP 2016c). Table 9 summarizes the estimated market share for the first 22 months after launch within the reference molecule (infliximab) as well as the entire rheumatology biological market, based on the analysis of wholesaler delivery contracts. Although the impact of budgetary constraint is often detectable in reimbursement decisions in Hungary (Boncz 2006), it seems that the biosimilar uptake lags behind compared to several higher income countries.

Table 9. Estimated market-share of biosimilar infliximab in Hungary, 22 months from launch (May 2014-February 2016)

\begin{tabular}{lccc}
\hline & Min* & Base & Max* \\
\hline Total expenditure on biologicals, bn HUF & 22.5 & 25.4 & 28.4 \\
Expenditure on originator infliximab (Remicade), bn HUF & 2.7 & 3.7 & 4.7 \\
Biosimilar infliximab (Inflectra), bn HUF & 0.6 & 0.8 & 1.0 \\
Biosimilar \% in infliximab expenditure & $12.9 \%$ & $21.6 \%$ & $36.7 \%$ \\
Biosimilar \% in total biological expenditure & $2.1 \%$ & $3.1 \%$ & $4.4 \%$ \\
\hline
\end{tabular}

*From optional contract values minimum and maximum market shares were calculated in a cross-over fashion (max: highest biosimilar value vs lowest market value, base: base biosimilar value vs base market value and min: lowest biosimilar value vs highest market value).

Source: OEP (2016b)

Due to the lack of systematic research about the uptake of biosimilar infliximab, only preliminary conclusions can be drawn when interpreting the market-share data across Europe. Differences of patent-expiry and tender dates may shift significantly the timing of effective launches, therefore cross-sectional market-share data cannot reveal the real uptake dynamics, especially during the early phase of the biosimilar launch. Also, differences of available treatment options, patient-access, professional guidelines and physician attitudes would warrant analysis of biosimilar uptake by indication or therapeutic area. As of writing this 
article, no research has been published about biosimilar utilization in rheumatology indications.

\subsection{Biosimilar price differentials}

In Norway high price differentials were connected with fast biosimilar uptake, however, the $69 \%$ discount levels in 2015 proved to be unsustainable and were diminished to $51 \%$ in subsequent tenders (epgonline.org 2015). As the cost analysis showed above, prices in public reimbursement lists may significantly differ from real net prices set in confidential procurement contracts. Due to the lack of reliable information about real net prices and patient numbers by brands, the effect of pricing on biosimilar infliximab uptake as well as saving estimates are not included in the scope of this article. The next sections will discuss other factors considered relevant for biosimilar market uptake.

\subsection{Differences between biosimilar and generic markets}

The market of generic drugs resembles perfect competition (Rittenberg and Tregarthen 2008). The evolving biosimilar market is different in several aspects. Currently there are only a limited number of biosimilar suppliers due to high technological and financial barriers to entry. Also, the distribution of information about prices or product utility is imbalanced among stakeholders. In addition, although by definition biosimilars deliver the same efficacy and safety as their reference products, public payers cannot treat them as homogenous products. Unlike generics, which can be automatically substituted by pharmacists, biosimilars can only be interchanged on the initiative or with the agreement of the prescribers (EGA 2016). The issue of interchangeability ${ }^{10}$ limits the applicable reimbursement policies and the achievable savings with biosimilars. Payer practices in addressing interchangeability vary significantly among countries in Europe.

Treating interchangeability in tenders ${ }^{11}$ is a complex issue. The Hungarian infliximab tender was split in two parts. Biosimilars could only compete for treatment naïve patients, while a separate tender was organized for patients already taking the originator reference product. Although the Hungarian system avoids forced switching ${ }^{12}$ of patients in case of alternating tender winners, physician driven interchange from the reference product to the biosimilar is limited. The early penetration of biosimilar infliximab in Hungary was among the fastest in Europe, while in 2015 uptake took a more moderate course compared to Poland or the Nordic countries. Since rheumatology disorders are chronic conditions, the share of new patients

\footnotetext{
${ }^{10}$ Interchangeability refers to the medical practice of changing one medicine for another that is equivalent, in a given clinical setting on the initiative or with the agreement of the prescriber. However, substitution refers to dispensing one medicine instead of another equivalent and interchangeable medicine at pharmacy level without requiring consultation with the prescriber. In case of automatic substitution, pharmacists are obliged to switch. (EGA 2016) Governed by national laws, substitutability is a key driver of generic competition. In most European countries biosimilars are interchangeable, but not substitutable, therefore several reimbursement techniques used in generic competition cannot be applied.

${ }^{11}$ Drugs used in hospitals and high value treatments, such as biologicals are procured in various national tenders in Hungary.

${ }^{12}$ Forced switching happens when without apparent medical reason or without the involvement of the prescriber patients are switched to another drug for economic reasons. This practice is equivalent to automatic substitution. (Dankó et al. 2011)
} 
within the total market is relatively low. Fast biosimilar uptake would require a marked increase in the number of new patients, in which case the budget impact would be hardly acceptable. Without allowing physician interchange, the saving potential with biosimilars in rheumatology seems to be limited.

A budget-impact analysis of biosimilar infliximab in Bulgaria, Czech Republic, Hungary, Poland, Romania and Slovakia demonstrated the marked effect of interchangeability on the potential savings in RA. Compared to the scenario which disallowed interchange, when allowing the interchange of $80 \%$ of patients from the originator to the biosimilar, the estimated savings were $36 \%$ greater (EUR $20.8 \mathrm{~m}$ vs $15.7 \mathrm{~m}$ ) in a 3 -year model. Also, when reinvesting savings, $42 \%$ more additional patients (1 709 versus 1205 ) could be treated from the same resource (Brodszky et al. 2014).

Unlike other European countries, automatic substitution to biosimilar infliximab is allowed in hospital tenders in Poland, leading to remarkably high penetration (EBE 2015). The Norwegian government funded the NOR-SWITCH study, a unique initiative to answer unresolved questions about the efficacy and safety of switching to biosimilar infliximab from the originator product. In this novel initiative the Norwegian government invested into scientific research with the involvement of practicing physicians in order to facilitate the implementation of effective interchange policies with marked cost-saving potential. The results are expected to be published in 2016 (Mack 2015). In Denmark interchange is recommended and with strong involvement of payers and regulators, biosimilar infliximab nearly replaced the originator by October 2015. With similar discount levels but no active recommendation of interchange, biosimilar infliximab could reach only $9.4 \%$ in Sweden within the same timeframe (Stanton 2016).

The new market conditions brought by biosimilars will bring innovation in reimbursement policies as the number of molecules and therapeutic areas will increase. Current experience suggests that limiting biosimilar usage only to naïve patient segments especially in chronic diseases may prevent payers from realizing the full economic benefit they could offer to healthcare systems (Thimmaraju et al. 2015).

\subsection{The role of the treating physicians}

Interchangeability requires the active involvement of the treating physicians, which implies that in addition to therapeutic decisions, physicians need to take economic considerations into account in order to realize the economic benefits of biosimilars. In addition to interchanging, several therapeutic decision points may have economic consequences, such as preferring the biosimilar versus other molecules in naïve patients, or preferring the biosimilar as a second line treatment over other alternatives with similar mechanism of action.

The available evidence from clinical trials in RA (Baji 2014a) and AS (Baji 2014b) suggests that biosimilar infliximab and potentially all biosimilars deliver similar therapeutic benefits as originals to most eligible patients. However, the market share data from Hungary and other European countries indicate that well over $90 \%$ of patients are treated with alternative originator biologicals. The role of physicians has been recognized by many European countries, and different incentives have been designed in order to enhance biosimilar 
utilization. In Norway and Denmark physicians are actively involved in the procurement process of medicines. In Spain physicians receive financial incentives if reaching biosimilar prescription targets. In Italy, part of the savings from biosimilars is automatically redirected to the budget dedicated for innovative medicines. In Germany biosimilar quotas have been set along with intense communication and education campaigns about the benefits of biosimilars (Aitken 2016). In the UK, hospitals share savings with regional payers treating gastroenterology patients with biosimilar infliximab (Emery and Hawkins 2015).

In Hungary the 2014 market-shares of filgrastim and erythropoietin biosimilars were 100\% and $75 \%$ respectively, mainly driven by tenders. Biosimilar growth hormone was reimbursed in a retail setting driven entirely by physician choices. Despite the $10 \%$ prescription quota, the biosimilar achieved only 6\% market-share (IMS Health 2015). No consistent enforcement or physician incentives were applied at the growth hormone market, nor incentives or quotas were set for biosimilar infliximab.

It has been hypothesized that the positive effect of biosimilars on patient-access will be an important incentive for physicians to prescribe biosimilars in the CEE region (Aitken 2016). A direct choice experiment study conducted with 51 gastroenterologists in Hungary revealed that although $77 \%$ of physicians had concerns, $92 \%$ of them would consider biosimilars if advances were offered in the reimbursement conditions benefiting their patients (Baji et al. 2016). Despite treating more patients with biologicals than gastroenterologists, no studies were published on the attitudes of rheumatologists in Hungary.

The 2014 entry of biosimilar infliximab had little effect on patient-access in Hungary so far. The treatment rate with biologicals in rheumatoid arthritis slightly declined when compared to 2013 (see Table 5). The introduction of the national biosimilar tender had similar effects. One year after the tender, the number of patients receiving biosimilar erythropoietin increased by $372.7 \%$, while the total number of treated patients decreased by $12.5 \%$. The budget saving on erythropoietins was $47.2 \%$ (1.1 bn HUF) during the first year after the tender. The use of biosimilar filgrastim increased by $130.4 \%$, while the number of patients receiving this therapy decreased by $4.5 \%$. The budget saving was $44.1 \%$ (3.3 bn HUF) in the first year after the tender (Hornyák et al. 2014). These findings suggest that despite the promise of better access, the market changes associated with biosimilar entry may even delivered counter-productive results on short-term patient access. However, the reported budget savings with filgrastim and erythropoietin biosimilars were significant. The budget savings with biosimilar infliximab in rheumatology indications are yet to be estimated.

\section{Conclusions}

The technological innovation of biological medicines resulted in considerable financial challenges for health care systems all over the world. Being less costly alternatives to originator biologicals, biosimilars drive competition and promise savings as well as the opportunity for better patient-access to biological treatment. However, due to the complexity of the biosimilar markets their full economic benefits have yet to be realized. The experiences with biosimilars are diverse and biosimilar reimbursement policies are still evolving.

In the near future the rheumatology biological market will be characterized by intensifying 
competition of multiple biosimilars. The considerable price discounts of originator biologicals driven by non-transparent arrangements in the tender procedures were probably important contributors to the relatively high level of access to rheumatology biologicals in Hungary compared to the CEE region. However, the level of access is still significantly below the Western European average.

The low price level of originators, the limited tender volume restricted to naïve patients and high risk of failure in single winner tenders limits the attractiveness of the Hungarian market of rheumatology biologicals for biosimilar players. In the first two years after launch, biosimilar infliximab gained less than 5\% market-share. Faster uptake would require the treatment of considerably more naïve patients, or interchanging already treated patients with the active involvement of physicians. Although physicians' willingness to prefer biosimilars could be positively influenced by subsequent advances in patient access, the experience so far indicated an initial neutral or even negative effect of biological treatment levels after biosimilar entries.

The experience with major Western European markets suggests that simultaneous education of physicians, patients and payers, as well as incentives for physicians and manufacturers are required to deliver the full economic benefits of biosimilars (Aitken 2016).

In Hungary, further research is recommended to systematically measure the effect of biosimilars on patient-access and realized savings by separate therapeutic areas. Also, the attitudes and expectations of different physician groups should be understood in order to improve collaboration between stakeholders. The establishment of policies supporting more interchange from the reference product as well as physician inventive systems for broader use should be considered in order to further drive biosimilar utilization and realize the full economic advantages offered by biosimilars in rheumatology indications.

\section{References}

ÁEEK (2016): Tételes Egészségügyi Adattár [National Health Database] http://tea.gyemszi.hu, accessed 29 March 2016.

Aitken, M. (2016): Delivering on the potential of biosimilar medicines - The role of functioning competitive markets. http://www.medicinesforeurope.com/wp-content / uploads/2016/03/IMS-Institute-Biosimilar-Report-March-2016-FINAL.pdf, accessed 18 February 2016.

Baji, P. - Péntek, M. - Czirják, L. - Szekanecz, Z. - Nagy, G. - Gulácsi, L. - Brodszky, V. (2014a): Efficacy and Safety of Infliximab-Biosimilar Compared to Other Biological Drugs in Rheumatoid Arthritis: A Mixed Treatment Comparison. The European Journal of Health Economics 15: 53-64.

Baji, P. - Péntek, M. - Szántó, S.- Géher, P. - Gulácsi, L. - Balogh, O. - Brodszky, V. (2014b): Comparative Efficacy and Safety of Biosimilar Infliximab and Other Biological Treatments in Ankylosing Spondylitis: Systematic Literature Review and Meta-analysis. The European Journal of Health Economics 15: 45-52. 
Baji, P. - Gulácsi, L. - Lovász, B.D. - Golovics, P.A. - Brodszky, V. - Péntek, M. - Rencz, F. - Lakatos, P.L. (2016): Treatment preferences of originator versus biosimilar drugs in Crohn's disease; discrete choice experiment among gastroenterologists.

Scandinavian Journal of Gastroenterology 51: 22-27.

Boncz, I. (2006): Prevention of cervical cancer in low-resource settings. JAMA 295. 1248; author reply 1249 .

Boncz, I. - Sebestyen, A. (2006): Financial deficits in the health services of the UK and Hungary. The Lancet 9593: 917.

Brodszky, V. - Baji, P. - Balogh, O. - Péntek, M. (2014): Budget Impact Analysis of Biosimilar Infliximab (CT-P13) for the Treatment of Rheumatoid Arthritis in Six Central and Eastern European Countries. The European Journal of Health Economics 15: $65-71$.

Catanoso, M. - Pipitone, N. - Salvarani. C. (2012): Epidemiology of psoriatic arthritis. Reumatismo 64: 66-70.

Credit Suisse (2014): USD CHF average exchange rate 2014. https://www.creditsuisse.com/media/production /pb/docs/unternehmen/kmugrossunternehmen/en/devisendurchschnittskurse-2014.pdf, accessed 26 March 2016.

Dankó, D. - Frang, G. - Girbicz, N. - Molnár, M. (2011). Alternatívák a biohasonló gyógyszerek fenntartható közfinanszírozási rendszerére. [Alternatives for sustainable public financing of biosimilars] http:// www.generikusegyesulet.hu/contents/uploads/documents/document_1328444930 700 .pdf, accessed 29 March 2016.

Daubenfeld, T. - Dassow, J. - Kessler, M. - Schulze, J. (2016): Understanding the market dynamics of biosimilars. Journal of Business Chemistry 13: 33-46.

Dean, L.E. - Jones, G.T. - MacDonald, A.G. - Downham, C. - Sturrock, R.D. - Macfarlane, G.J. (2014): Global prevalence of ankylosing spondylitis. Rheumatology 53: 650-657.

Dorner, T. - Strand, V. - Cornes, P. - Goncalves, J. - Gulacsi, L. - Kay, J. - Kvien, T. K. Smolen, J. - Tanaka Y. - Burmester G.R. (2016): The changing landscape of biosimilars in rheumatology. Annals of the Rheumatic Diseases 75(6): 974-982.

EBE (2015): What pricing and reimbursement policies to use for off-patent biologicals? Results from the EBE 2014 biological medicines policy survey. Generics and Biosimilars Initiative Journal 4: 17-24.

EGA (2016): Biosimilars Handbook http://www. medicinesforeurope.com/2016/02/19/ biosimilars-handbook/, accessed 4 October 2016.

EMA (2016a): European public assessment reports http://www.ema.europa.eu/ema/ index.jsp?curl $=$ pages $\% 2$

Fmedicines\%2Flanding\%2Fepar_search.jsp\&mid=WC0b01ac058001d124\&searchTa $\mathrm{b}=$ searchByAuthType\&alreadyLoaded=true\&isNewQuery=true\&status=Authorised $\&$ status $=$ Withdrawn\&status $=$ Suspended\&status $=$ Refused \&keyword $=$ Enter + keywords $\&$ searchType=name\&taxonomyPath $=\&$ treeNumber $=\&$ searchGenericType=biosimilars \&genericsKeywordSearch=Submit, accessed 18 February 2016. 
EMA (2016b): Q\&A: Similar biological products - Biosimilar medicines

http://www.ema.europa.eu/ema/index.

jsp?curl=pages/special_topics/document_listing/document_listing_000318.jsp,

accessed 18 February 2016.

EMA (2016c): Medicines under evaluation

http://www.ema.europa.eu/ema/index.jsp?curl=pages/medicines/

document_listing/document_listing_000349.jsp\&mid=WC0b01ac05805083eb, accessed 20 February 2016.

Emerton, D.A. (2013): Profitability in the Biosimilars Market http://www

.bioprocessintl.com/upstream-processing/upstream-contract-services/profitability-inthe-biosimilars-market-344001/, accessed 20 February 2016.

Emery, P. - Hawkins, T. (2015): Biosimilar medicines in rheumatology. http:// www. pharmaceutical-journal.com/learning/learning-article/biosimilar-medicines-inrheumatology /20200018. article, accessed 20 February 2016.

epgonline.org. (2015): Price cutting of biosimilar infliximab drugs in Norway- Hospira and Orion Oyj. http:// www.epgonline.org/news/price-cutting-of-biosimilar-infliximabdrugs-in-norway-hospira.cfm, accessed 10 April 2016.

EUMUSC (2011): Musculoskeletal Health in Europe Report v5.0.

http://www.eumusc.net/myUploadData/

files/Musculoskeletal\%20Health\%20in\%20Europe\%20Report\%20v5.pdf, accessed 20

February 2016.

Evaluate Pharma. (2015): EvaluatePharma World Preview 2015 - Outlook to 2020 http://www.evaluategroup. com/public/reports/EvaluatePharma-World-Preview2015.aspx, accessed 20.February 2016.

Gulácsi, L. - Brodszky, V. - Baji, P. - Kim, H. - Kim, S.Y. - Cho, Y.Y. - Péntek, M. (2015): Biosimilars for the management of rheumatoid arthritis: economic considerations. Expert Review of Clinical Immunology 11(S1): 43-52.

Gulácsi, L. - Rencz, F. - Péntek, M. - Brodszky, V. - Lopert, R. - Hevér, N.V. - Baji, P. (2014): Transferability of results of cost utility analyses for biologicals in inflammatory conditions for Central and Eastern European countries. The European Journal of Health Economics 15: 27-34.

Gulácsi, L. - Rencz, F. - Poór, G. - Szekanecz, Z. - Brodszky, V. - Baji, P. - Péntek, M. (2016): Patients' access to biological therapy in chronic inflammatory conditions; per capita GDP does not explain the intercountry differences. Annals of the Rheumatic Diseases annrheumdis-2015-208741. doi:10.1136/annrheumdis-2015-208741

Hanova, P. - Pavelka, K. - Dostal, C. - Holcatova, I. - Pikhart, H. (2006): Epidemiology of rheumatoid arthritis. juvenile idiopathic arthritis and gout in two regions of the Czech Republic in a descriptive population-based survey in 2002-2003. Clinical and Experimental Rheumatology 24: 499-507.

Hanova, P. - Pavelka, K. - Holcatova, I. - Pikhart, H. (2010): Incidence and prevalence of psoriatic arthritis. ankylosing spondylitis. and reactive arthritis in the first descriptive population-based study in the Czech Republic. Scandinavian Journal of Rheumatology 39: $310-317$. 
Healthware Tanácsadó Kft. (2015). A gyógyszerfinanszírozási piac aktuális kérdései [Burning issues of the pharmaceutical reimbursement market] http://

www.healthware.hu/files/newsletter/HW_Hirlevel_2015_julius.pdf, accessed 30 July 2016.

Hoffmann La Roche Ltd. (2014): Roche Annual Report. http://www.roche.com/investors/reporting/ar14_highlights .htm, accessed 26 March 2016.

Hornyák, L. - Nagy, Z. - Tálos, Z. - Endrei, D. - Ágoston, I. - Csákvári, T. - Boncz, I. (2014) A biohasonló gyógyszerek árversenyének tapasztalatai Magyarországon. [Experiences with price competition of biosimilar drugs in Hungary] Acta Pharmaceutica Hungarica 2014(2): 1-5.

IMS Health. (2015): The Impact of Biosimilar Competition. http://www. medicinesforeurope.com/2015/11/01/ the-impact-of-biosimilar-competition/, accessed 20 February 2016.

Johnson \& Johnson Ltd. (2014): Johnson \& Johnson Annual Report. http://www.investor.jnj.com /secfiling. $\mathrm{cfm}$ ?filingid=200406-15-4\&cik=, accessed 26 March 2016.

Kiss, C.G. - Lövei, C. - Sütö, G. - Varjú, C. - Nagy, Z. - Füzesi, Z. - Illés, T. - Czirják, L. (2005): Prevalence of rheumatoid arthritis in the South-Transdanubian region of Hungary based on a representative survey of 10.000 inhabitants. The Journal of Rheumatology 32: 1688-1690.

KSH (2016): 6.1.2. A lakónépesség korcsoport szerint, január 1. [6.1.2. Population by age groups $1^{\text {st }}$ January] http://www.

ksh.hu/docs/hun/xstadat/xstadat_eves/i_wdsd004b.html, accessed 26 March 2016.

Kobelt, G. - Kasteng, F. (2009): Access to innovative treatments in rheumatoid arthritis in Europe. A report prepared for the European Federation of Pharmaceutical Industry Associations (EFPIA) http://www.comparatorreports.se/Access\%20to\%20 RA\%20Treatments\%20October\%202009.pdf, accessed 27 March 2016.

Kobelt, G. - Sobocki, P. - Mulero, J. - Gratacos, J. - Pocovi, A. - Collantes-Estevez, E. (2008): The Burden of Ankylosing Spondylitis in Spain. Value in Health 11: 408-415.

Laki, J. - Mónok, G. - Pálosi, M. - Gajdácsi, J.Z. (2013): Economical aspect of biological therapy in inflammatory conditions in Hungary. Expert Opinion on Biological Therapy 13: 327-337.

Lekander, I. - Borgström, F. - Lysholm, J. - van Vollenhoven, R. F. - Lindblad, S. Geborek P. - Kobelt G. (2013). The cost-effectiveness of TNF-inhibitors for the treatment of rheumatoid arthritis in Swedish clinical practice. The European Journal of Health Economics 14(6): 863-873.

Mack, A. (2015): Norway. biosimilars in different funding systems. What works? Generics and Biosimilars Initiative Journal 4: 90-92.

Magyar Államkincstár. (2014): TB Alapok Mérlege [Balance of Healthcare Funds] http://www.allamkincstar .gov.hu/hu/koltsegvetesi-informaciok /koltsegvetes_merleg_4/225/, accessed 27 March 2016.

Nisen, M. (2016): The best selling prescription drugs in the world last year. http://qz.com/349929/best-selling-drugs-in-the-world/, accessed 20 February 2016. 
OEP (2016a). Gyógyszerforgalmi adatok: éves riport 2015. [Pharmaceutical sales data: annual report 2015]

http://www.oep.hu/felso_menu/szakmai_oldalak/publikus_forgalmi_adatok/gyogyszer _forgalmi_adatok, accessed: 30 July 2016.

OEP (2016b): teteles.oep.hu [itemized accounts webpage] http://teteles.oep.hu/, accessed 10 April 2016.

OEP (2016c): Közbeszerzési eljárások [Public procurement procedures] http://www.oep.hu/felso_menu/rolunk/kozerdeku_adatok/kozbeszerzesi _informaciok/kozbeszerzesi_eljarasok, accessed 27 March 2016.

Orlewska, E. - Ancuta, I. - Anic, B. - Codrenau, C. - Damjanov, N. - Djukic, P. - Ionescu, R. - Marinchev, L. - Nasonov, E.L. - Peets, T. - Praprotnik, S. - Rashkov, R. Skoupa, J. - Tlustochowicz, W. - Tlustochowicz, M. - Tomsic, M. - Veldi, T. Vojinovic, J. - Wiland, P. (2011): Access to biologic treatment for rheumatoid arthritis in Central and Eastern European (CEE) countries. Medical Science Monitor 17: SR1-SR13.

Péntek, M. - Poór, G. - Wiland, P. - Olejárova, M. - Brzosko, M. - Codreanu, C. Brodszky, N. - Gulácsi, L. (2014): Biological Therapy in Inflammatory Rheumatic Diseases: Issues in Central and Easter European Countries. The European Journal of Health Economics 15(S1): S35-S43.

Poór, G. (2015): Tízéves az arthritisek biológiai terápiás ellátása Magyarországon. [The biological therapy of arthritides is 10 years old in Hungary] Hungarian Rheumatology 56: 199-207.

Putrik, P. - Ramiro, S. - Kvien, T. - Sokka, T. - Pavlova, M. - Uhlig, T. - Boonen, A. (2014): Inequities in access to biologic and synthetic DMARDs across 46 European countries. Annals of the Rheumatic Diseases 73: 198-206.

PMLiVE (2014): Top 50 pharmaceutical products by global sales. http://www.pmlive.com/top_pharma_list/Top_50 _pharmaceutical_products_by_global_sales, accessed 7 April 2016.

Rittenberg, L. - Tregarthen, T. (2008): Principles of Microeconomics. Nyack: Flat World Knowledge.

Reveille, J.D. - Ximenes, A. - Ward, M.M. (2012): Economic Considerations of the Treatment of Ankylosing Spondylitis. American Journal of Medical Science 343: 371-374.

Stanton, D. (2016): Biosimilar discounts and switching will wipe-out J\&J's Remicade in Norway says regulator. http://www.biopharma-reporter.com/MarketsRegulations/Biosimilar-discounts-will-wipe-out-Janssen-s-Remicade-sales-inNorway, accessed 17 April 2016.

Statista (2016a): Bristol-Myers Squibb top-products revenues 2008-2015. Statistic http://www.statista.com /statistics/266585/bristol-myers-squibbs-top-products-basedon-revenue/, accessed 26 March 2016.

Statista (2016b): EUR USD annual average exchange rate 1999-2015. Statistic. http://www.statista.com /statistics/412794/euro-to-u-s-dollar-annual-averageexchange-rate/, accessed 26 March 2016. 
Thimmaraju, P.K. - Rakshambikai, R. - Farista, R. - Juluru, K. (2015): Legislations on biosimilar interchangeability in the US and EU - developments far from visibility http://www.gabionline.net/ Sponsored-Articles/Legislations-on-biosimilarinterchangeability-in-the-US-and-EU-developments-far-from-visibility, accessed 10 April 2016.

WHO (2011). International Nonproprietary Names (INN) for biological and biotechnological substances (a review). Geneva: WHO.

Zeidler, J., - Mittendorf, T. - Müller R. - von Kempis J. (2012). Biologic TNF inhibiting agents for treatment of inflammatory rheumatic diseases: dosing patterns and related costs in Switzerland from a payers perspective. Health Economics Review 2(1): 1-8. 